\title{
Reconstructing
}

lives

Victims of war in the

Middle East and

Médecins Sans Frontières

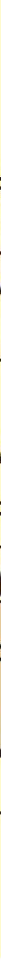




\section{Reconstructing lives}

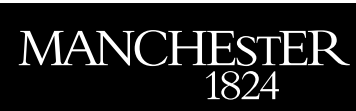

Manchester University Press 


\section{HUMANITARIANISM}

\section{KEY DEBATES \& NEW APPROACHES}

\section{SERIES EDITOR: BERTRAND TAITHE}

This series offers a new interdisciplinary reflection on one of the most important and yet understudied areas in history, politics and cultural practices: humanitarian aid and its responses to crises and conflicts. The series seeks to define afresh the boundaries and methodologies applied to the study of humanitarian relief and so-called 'humanitarian events'. The series includes monographs and carefully selected thematic edited collections which cross disciplinary boundaries and bring fresh perspectives to the historical, political and cultural understanding of the rationale and impact of humanitarian relief work.

\section{Islamic charities and Islamic humanism in troubled times}

Jonathan Benthall

Humanitarian aid, genocide and mass killings: Médecins Sans Frontières, the Rwandan experience, 1982-97

Jean-Hervé Bradol and Marc Le Pape

Calculating compassion: Humanity and relief in war, Britain 1870-1914

Rebecca Gill

Humanitarian intervention in the long nineteenth century

Alexis Heraclides and Ada Dialla

The military-humanitarian complex in Afghanistan

Eric James and Tim Jacoby

Global humanitarianism and media culture

Michael Lawrence and Rachel Tavernor (eds)

Aid to Armenia: Humanitarianism and intervention from the 1890 s to the present Jo Laycock and Francesca Piana (eds)

A history of humanitarianism, 1775-1989: In the name of others Silvia Salvatici

Donors, technical assistance and public administration in Kosovo Mary Venner

The NGO CARE and food aid from America 1945-80: 'Showered with kindness'? Heike Wieters

The Red Cross movement: Myths, practices and turning points

Neville Wylie, James Crossland, Melanie Oppenheimer (eds) 


\title{
Reconstructing lives
}

\section{Victims of war in the Middle East and Médecins Sans Frontières}

\author{
Vanja Kovačič
}

Manchester University Press 
The right of Vanja Kovačič to be identified as the author of this work has been asserted by them in accordance with the Copyright, Designs and Patents Act 1988.

Published by Manchester University Press

Oxford Road, Manchester M13 9PL

www.manchesteruniversitypress.co.uk

British Library Cataloguing-in-Publication Data

A catalogue record for this book is available from the British Library

ISBN 9781526161611 hardback

First published 2021

The publisher has no responsibility for the persistence or accuracy of URLs for any external or third-party internet websites referred to in this book, and does not guarantee that any content on such websites is, or will remain, accurate or appropriate.

Cover image: Male relatives gathered around their injured family member. Illustration by Sarah Imani.

\section{Typeset}

by Sunrise Setting Ltd 